\title{
Effect of Seed Rate and Nitrogen Level on Growth and Yield of Fodder Sorghum under Custard Apple Based Horti-Pastoral System
}

\author{
Sanjiv Yadav, U. Sai Sravan*, Tikendra Kumar Yadav and S.P. Singh \\ Department of Agronomy, Institute of Agricultural Sciences, Banaras Hindu University, \\ Varanasi - 221005 , U.P., India \\ *Corresponding author
}

\begin{tabular}{|c|c|}
\hline & A B S T R A C T \\
\hline $\begin{array}{l}\text { Seed rate, Nitrogen } \\
\text { level, Fodder } \\
\text { sorghum, Fodder } \\
\text { yield, Custard } \\
\text { apple. }\end{array}$ & \multirow{3}{*}{ 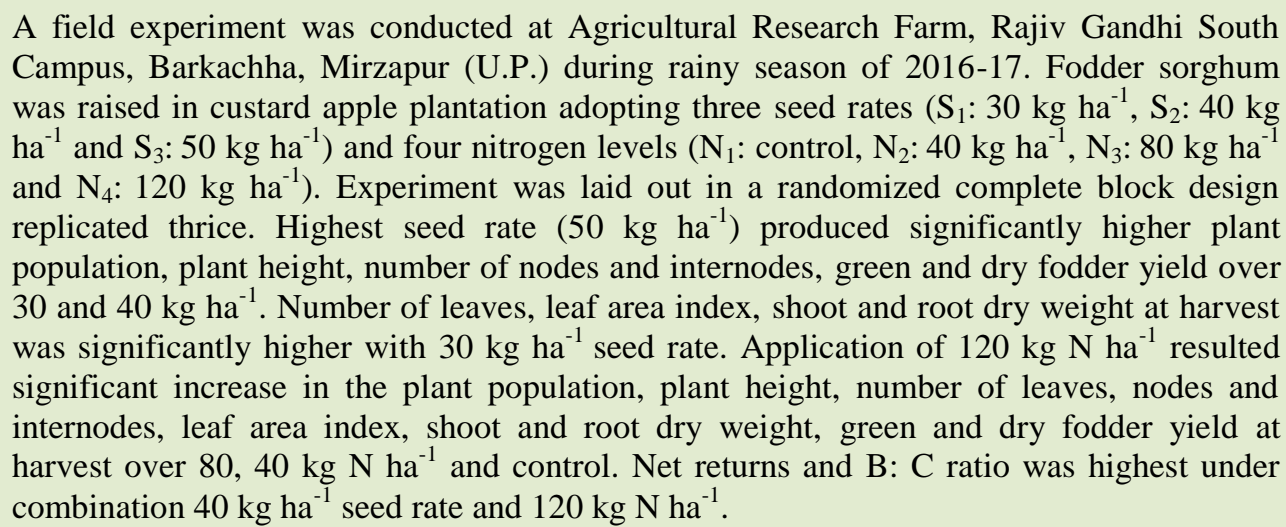 } \\
\hline Article Info & \\
\hline $\begin{array}{l}\text { Accepted: } \\
\text { 12 October } 2017 \\
\text { Available Online: } \\
\text { 10 December } 2017\end{array}$ & \\
\hline
\end{tabular}

\section{Introduction}

Combination of fruit trees and pasture (Hortipastoral) in an agroforestry system increases overall production besides imparting stability to the farming. The general perception of farmers is not to grow agricultural crops in combination of the trees (Bargali et al., 2004). Horti-pastoral systems are popular worldwide and promising option due to their increased return per unit area, high market value of product and contribution of fruits to household dietary needs. In India, custard apple (Annona squamosa) is cultivated in an area of 22,000 ha with production of 1 , 65,000 tonnes (Anonymous, 2015a). Demand for food and fodder shows an ever increasing trend because of the growing population. Interspaces between fruit trees may be utilized for growing short duration crops like fodder sorghum under rainfed condition. Rainfed areas with fluctuation in rainfall pattern needs appropriate crop selection and sorghum is most suitable because of its relative drought tolerance.

Sorghum is the fourth most important cereal crop of India, next to rice, wheat and maize cultivated in an area of 5.8 million hectare with production of 5.54 million tonnes and productivity of $956 \mathrm{~kg} \mathrm{ha}^{-1}$ (Anonymous, 2015b). Sorghum is an important kharif 
season fodder crop occupies maximum area (2.8 $\mathrm{m}$ ha) due to its high production potential, wider adaptability, quick growing nature, succulence, palatability, excellent fodder quality and can be safely fed to animal at flowering stage. To harvest the higher fodder yield agronomic factors such as seed rate and nitrogen level are important. Low or excessive plant population may lead to reduction in the overall efficiency of the crop (Prajapati et al., 2017). Hence, seed rate is key input for getting higher yields and efficient use of resources.

Fertilizer application is the principal factor markedly affects the fodder yield. Nitrogen is an essential nutrient for physiological, growth and yield point of view (Alloway, 2004), but at the same time establishment of an optimum plant stand is equally important to get maximum yield (Reddy and Reddy, 2010). Adequate nitrogen should be applied to a crop when needed. Studies with sorghum have shown that fertilizer knifed-in at planting increases yields than to broadcast application (Sweeney, 1989; Khosla et al., 2000). Information's on optimum seed rate and nitrogen level required to maximize yield of fodder sorghum in a horti-pastoral system. The objective of present study was to evaluate the growth, yield and economics of kharif fodder sorghum to different seed rates and levels of nitrogen in Vindhyan region.

\section{Materials and Methods}

\section{Experimental area and treatment details}

The experiment was carried out at Agricultural Research Farm, Rajiv Gandhi South Campus, Brakachha, Banaras Hindu University, Mirzapur situated at $25^{\circ} 15^{\prime}$ latitude and $82^{\circ} 60^{\prime}$ longitudes, and at an altitude of 427 meters above mean sea level. An experiment was laid out during rainy (kharif) season of 2016 in a factorial randomized complete block design with three seed rates $\left(S_{1}: 30 \mathrm{~kg} \mathrm{ha}^{-1}, \mathrm{~S}_{2}: 40 \mathrm{~kg} \mathrm{ha}^{-1}\right.$ and $\mathrm{S}_{3}$ : $\left.50 \mathrm{~kg} \mathrm{ha}^{-1}\right)$ and four nitrogen levels $\left(\mathrm{N}_{1}\right.$ : control, $\mathrm{N}_{2}: 40 \mathrm{~kg} \mathrm{ha}^{-1}, \mathrm{~N}_{3}: 80 \mathrm{~kg} \mathrm{ha}^{-1}$ and $\mathrm{N}_{4}$ : $120 \mathrm{~kg} \mathrm{ha}^{-1}$ ), replicated thrice. Experimental crop fodder sorghum variety MFSH-4 (RASEELA) was sown as intercrop at a row distance of $30 \mathrm{~cm}$ manually in the alleys of nine year old custard apple planted in August, 2006 at a spacing of $5 \times 5 \mathrm{~m}^{2}$. Composite soil samples prior to the experiment were analyzed for different physico-chemical properties of the soil. The soil of the experimental field was sandy clay loam in texture, acidic in reaction with $\mathrm{pH} 5.4$, EC of $0.30 \mathrm{dSm}^{-1}$, low in organic carbon $(0.27 \%)$, available nitrogen $\left(183.67 \mathrm{~kg} \mathrm{ha}^{-1}\right)$ and phosphorus (16.76 kg ha $\mathrm{kg}^{-1}$ ) and medium in available potassium $\left(183.25 \mathrm{~kg} \mathrm{ha}^{-1}\right)$. Field was ploughed with the help of disc plough and harrowing was done followed by planking.

Recommended dose of phosphorus @ $60 \mathrm{~kg}$ $\mathrm{ha}^{-1}$ and potassium @ $40 \mathrm{~kg} \mathrm{ha}^{-1}$ were applied in the form of diammonium phosphate and muriate of potash respectively. Nitrogen was applied through urea as per the treatments; half as basal and remaining half was top dressed after 30 days of sowing. The rainfall received during crop season was about 179.87 $\mathrm{mm}$. Recommended agronomic practices were followed to raise the crop.

\section{Growth attributes and yield}

Initial and final plant population was recorded at 15 DAS and harvest respectively, expressed in $\mathrm{m}^{2}$. Five plants from net plot were tagged to record biometric observations. Plant height was measured from base of the plants to growing tip of main stem and expressed in $\mathrm{cm}$. Number of leaves, leaf area index (LAI), nodes and internodes from five plants were recorded at harvest. Plant biomass at harvest of five plants from border rows in each plot 
were cut from the ground level. Roots of plants were extracted with the help of soil cores around the plant in row from five places. The roots are separated from the surrounding soil over a sieve by hand such that the total roots were kept intact (Prathapar et al., 1989), washed in water to remove adhered soil. Thereafter, shoots and roots were sundried for 2-3 days separately and oven dried at $70^{\circ} \mathrm{C}$ for 48 hours to get constant weight and expressed as g plant ${ }^{-1}$. First the border rows were harvested, bundled and removed from the plot.

Then the crop from net plot area of $13.6 \mathrm{~m}^{-2}$ was harvested close to the ground, bundled and weighed as green fodder yield and expressed in $\mathrm{q} \mathrm{ha}^{-1}$. The harvested produce was sundried for 4 days, weighed and expressed as dry fodder yield in $\mathrm{q} \mathrm{ha}^{-1}$.

\section{Economics}

Economics of treatments was calculated separately by taking into account the existing price of inputs and produce. Gross return was calculated by multiplying the green fodder yield with the prevailing market price (Rs $2.50 \mathrm{~kg}^{-1}$ ). Net return and benefit: cost ratio was worked out with the help of the following formulas:

Net return $\left(\right.$ Rs ha $\left.^{-1}\right)=$ Gross return $\left(\mathrm{Rs} \mathrm{ha}^{-1}\right)-$ Cost of cultivation ( $\mathrm{Rs} \mathrm{ha}^{-1}$ )

Benefit: cost ratio $=$ - Net return (Rs ha-1)

Cost of cultivation (Rs ha-1)

\section{Statistical analysis}

Data collected on growth parameters and yields of the experimental crop were tabulated and statistically analyzed as per the standard analysis of variance (Gomez and Gomez, 1984).

\section{Results and Discussion}

\section{Plant population and plant height}

Plant population (initial and final) of fodder sorghum altered significantly with seed rate (Table 1). As seed rate increased plant population increased and highest values was obtained with highest seed rate $\left(50 \mathrm{~kg} \mathrm{ha}^{-1}\right)$. The plant density is mainly governed by seed rate and similar findings were reported by Ayub et al., (2007). Nitrogen levels brought significant variation in plant population (initial and final), registered maximum with highest level of nitrogen (120 kg ha-1). Abuswar and Mohammed (1997) emphasized nitrogen fertilization had a significant effect on plant density. Plant height continuously increased with age of plant; taller plants at harvest were produced due to seed rate of 50 $\mathrm{kg} \mathrm{ha}^{-1}$ followed by $40 \mathrm{~kg} \mathrm{ha}^{-1}$ and $30 \mathrm{~kg} \mathrm{ha}^{-1}$ (Table 1). Plant height is controlled by their genetic makeup and interaction with environment to which plants are subjected during the growth and development (Mahdi et al., 2011). Nitrogen application @ $120 \mathrm{~kg} \mathrm{ha}^{-1}$ recorded significantly superior plant height at harvest over other nitrogen levels (Table 1).

This may be attributed to sufficient availability and more uptake of nitrogen by crop ultimately resulted in better vegetative growth. These findings are in accordance with Abuswar and Mohammed (1997). Interaction of seed rate and nitrogen levels could not differ significantly.

\section{Number of leaves and LAI}

Number of leaves and LAI significantly differed with seed rate (Table 1). Number of leaves and LAI were highest with lower seed rate of $30 \mathrm{~kg} \mathrm{ha}^{-1}$. However, highest seed rate resulted in lowest values. This response was expected with lower seed rate due to better access to nutrients, sunlight and moisture. 
Table.1 Effect of seed rate and nitrogen levels on growth of fodder sorghum at harvest grown as custard apple based horti-pastoral system

\begin{tabular}{|c|c|c|c|c|c|c|c|}
\hline \multirow[t]{2}{*}{ Treatments } & \multicolumn{2}{|c|}{$\begin{array}{c}\text { Plant } \\
\text { population }\end{array}$} & \multirow{2}{*}{$\begin{array}{c}\text { Plant } \\
\text { height } \\
\text { (cm) }\end{array}$} & \multirow{2}{*}{$\begin{array}{l}\text { No. of } \\
\text { leaves } \\
\text { plant }^{-1}\end{array}$} & \multirow[t]{2}{*}{ LAI } & \multirow{2}{*}{$\begin{array}{c}\text { No. of } \\
\text { nodes } \\
\text { plant }^{-1}\end{array}$} & \multirow{2}{*}{$\begin{array}{c}\text { No. of } \\
\text { internodes } \\
\text { plant }^{-1}\end{array}$} \\
\hline & Initial & Final & & & & & \\
\hline \multicolumn{8}{|c|}{ Seed rate $\left(\mathrm{kg} \mathrm{ha}^{-1}\right)$} \\
\hline $\mathrm{S}_{1}: 30$ & 26.77 & 23.83 & 172.67 & 10.62 & 11.71 & 5.95 & 4.71 \\
\hline $\mathrm{S}_{2}: 40$ & 30.32 & 27.33 & 195.53 & 8.60 & 9.48 & 6.74 & 5.65 \\
\hline $\mathrm{S}_{3}: 50$ & 37.43 & 34.41 & 241.39 & 7.59 & 8.37 & 8.33 & 7.53 \\
\hline SEm \pm & 0.64 & 0.63 & 4.16 & 0.18 & 0.20 & 0.14 & 0.17 \\
\hline $\operatorname{LSD}(P=0.05)$ & 1.89 & 1.87 & 12.22 & 0.53 & 0.59 & 0.42 & 0.50 \\
\hline \multicolumn{8}{|c|}{ Nitrogen levels $\left(\mathrm{kg} \mathrm{ha}^{-1}\right)$} \\
\hline $\mathrm{N}_{1}$ : control & 24.25 & 21.33 & 156.39 & 6.88 & 7.58 & 5.39 & 4.03 \\
\hline $\mathrm{N}_{2}: 40$ & 30.44 & 27.22 & 196.27 & 8.63 & 9.52 & 6.77 & 5.68 \\
\hline $\mathrm{N}_{3}: 80$ & 33.84 & 30.88 & 218.22 & 9.60 & 10.58 & 7.53 & 6.58 \\
\hline $\mathrm{N}_{4}: 120$ & 37.51 & 34.66 & 241.91 & 10.64 & 11.73 & 8.34 & 7.56 \\
\hline SEm \pm & 0.74 & 0.73 & 4.81 & 0.21 & 0.23 & 0.16 & 0.19 \\
\hline $\operatorname{LSD}(P=0.05)$ & 2.18 & 2.16 & 14.11 & 0.62 & 0.68 & 0.48 & 0.58 \\
\hline Interaction & NS & NS & NS & NS & NS & NS & NS \\
\hline
\end{tabular}

Table.2 Effect of seed rate and nitrogen levels on dry weight and yields of fodder sorghum grown as custard apple based horti-pastoral system

\begin{tabular}{|c|c|c|c|c|}
\hline \multirow[t]{2}{*}{ Treatments } & \multicolumn{2}{|c|}{ Dry weight plant $^{-1}(\mathrm{~g})$} & \multicolumn{2}{|c|}{ Fodder yield (q ha $\left.{ }^{-1}\right)$} \\
\hline & Shoot & Root & Green & Dry \\
\hline \multicolumn{5}{|c|}{ Seed rate $\left(\mathrm{kg} \mathrm{ha}^{-1}\right)$} \\
\hline $\mathrm{S}_{1}: 30$ & 19.91 & 3.06 & 84.07 & 28.02 \\
\hline $\mathrm{S}_{2}: 40$ & 16.12 & 2.48 & 109.45 & 35.06 \\
\hline $\mathrm{S}_{3}: 50$ & 14.24 & 2.19 & 117.11 & 39.34 \\
\hline $\mathrm{SEm} \pm$ & 0.34 & 0.05 & 2.46 & 0.70 \\
\hline $\operatorname{LSD}(P=0.05)$ & 1.00 & 0.15 & 7.21 & 2.06 \\
\hline \multicolumn{5}{|c|}{ Nitrogen levels $\left(\mathrm{kg} \mathrm{ha}^{-1}\right)$} \\
\hline $\mathrm{N}_{1}$ : control & 12.90 & 1.98 & 83.37 & 26.49 \\
\hline $\mathrm{N}_{2}: 40$ & 16.19 & 2.49 & 99.12 & 32.96 \\
\hline $\mathrm{N}_{3}: 80$ & 18.00 & 2.77 & 109.92 & 36.75 \\
\hline $\mathrm{N}_{4}: 120$ & 19.95 & 3.07 & 121.78 & 40.37 \\
\hline $\mathrm{SEm} \pm$ & 0.39 & 0.06 & 2.84 & 0.81 \\
\hline $\operatorname{LSD}(P=0.05)$ & 1.16 & 0.17 & 8.33 & 2.38 \\
\hline Interaction & NS & NS & NS & NS \\
\hline
\end{tabular}


Table.3 Relative economics of fodder sorghum as influenced by seed rate and nitrogen levels grown as custard apple based horti-pastoral system

\begin{tabular}{cccc}
\hline Treatments & Gross return $^{*}\left(\mathbf{R s ~ h}^{-1}\right)$ & Net return $\left(\mathbf{R s ~ h}^{\mathbf{1}}\right)$ & Benefit: cost ratio \\
\hline $\mathrm{S}_{1} \mathrm{~N}_{1}$ & 50228.00 & 34298.20 & 2.15 \\
$\mathrm{~S}_{1} \mathrm{~N}_{2}$ & 53745.50 & 37599.58 & 2.32 \\
$\mathrm{~S}_{1} \mathrm{~N}_{3}$ & 55890.50 & 39223.78 & 2.35 \\
$\mathrm{~S}_{1} \mathrm{~N}_{4}$ & 58083.00 & 40895.48 & 2.37 \\
$\mathrm{~S}_{2} \mathrm{~N}_{1}$ & 55750.50 & 38870.70 & 2.30 \\
$\mathrm{~S}_{2} \mathrm{~N}_{2}$ & 58388.00 & 41292.08 & 2.41 \\
$\mathrm{~S}_{2} \mathrm{~N}_{3}$ & 62243.00 & 44626.28 & 2.53 \\
$\mathrm{~S}_{2} \mathrm{~N}_{4}$ & 66945.50 & 48807.98 & 2.69 \\
$\mathrm{~S}_{3} \mathrm{~N}_{1}$ & 56953.00 & 39123.20 & 2.19 \\
$\mathrm{~S}_{3} \mathrm{~N}_{2}$ & 62610.50 & 44564.58 & 2.46 \\
$\mathrm{~S}_{3} \mathrm{~N}_{3}$ & 64708.00 & 46141.28 & 2.48 \\
$\mathrm{~S}_{3} \mathrm{~N}_{4}$ & 66715.50 & 47627.98 & 2.49 \\
\hline
\end{tabular}

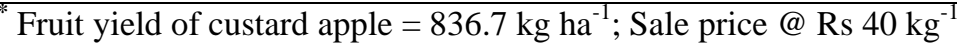

Reduction in leaf area index at higher seed rates because of increased competition for light and space also observed by Valadabadi and Farhani (2010). Highest dose of nitrogen $\left(120 \mathrm{~kg} \mathrm{ha}^{-1}\right)$ recorded significantly maximum number of leaves and LAI than rest of the nitrogen levels (Table 1).

Nitrogen enhanced protein synthesis and consequently vegetative growth. Increase in number of leaves and LAI more photosynthetic surface and further stimulated the growth. Higher leaves plant ${ }^{-1}$ and LAI due to nitrogen application have been reported by Ahmad et al., (2011), Osman et al., (2010) and Patil et al., (2014). The interaction between seed rate and nitrogen levels was non-significant.

Number of nodes, internodes and dry weight

Number of nodes and internodes significantly varied and maximum values recorded by seed rate of $50 \mathrm{~kg} \mathrm{ha}^{-1}$ followed by $40 \mathrm{~kg} \mathrm{ha}^{-1}$ and $30 \mathrm{~kg} \mathrm{ha}^{-1}$, respectively at harvest (Table 1). Higher seed rate resulted increase in plant density and plant height and ultimately produced more number of nodes and internodes. Shoot and root dry weight altered with seed rate (Table 2), highest dry weight noticed with lowest seed rate $\left(30 \mathrm{~kg} \mathrm{ha}^{-1}\right)$. With increase in the seed rate dry weight reduced considerably because of less number of leaves and reduction in LAI. Dry matter production is directly related to quantum of solar radiation intercepted by the canopy. Lower plant density facilitates rapid expansion of the canopy and their by interception of more radiation. Similar findings for seed rate and their effect on nodes and internodes, shoot and root dry weight reported by Ayub et al., (2007) and Valadabadi and Farhani (2010). Highest number of nodes and internodes (Table 1), dry weight of shoot and root noted by addition of highest nitrogen level $\left(120 \mathrm{~kg} \mathrm{ha}^{-}\right.$ ${ }^{1}$ ) at harvest (Table 2).

More nitrogen provided larger photosynthetic surface area to intercept more radiant energy consecutively resulting higher shoot and root dry matter. Similar results were reported by Singh et al., (2005). Enhancement in nitrogen levels significantly increases number and length of internodes plant ${ }^{-1}$ (Patil et al., 2014). The interaction of seed rate and nitrogen levels remained non-significant. 


\section{Yield}

Seed rate caused significant difference in the green and dry fodder yield. Maximum green and dry fodder yield produced by highest seed rate $\left(50 \mathrm{~kg} \mathrm{ha}^{-1}\right)$ followed by $40 \mathrm{~kg} \mathrm{ha}^{-1}$ and $30 \mathrm{~kg} \mathrm{ha}^{-1}$ (Table 2). Enhancement in fodder yield with seed rate could be attributed to increased plant population and height, optimum number of leaves, LAI and dry matter. Ayub et al., (1999), Patel et al., (2004), Malik et al., (2007) and Osman et al., (2010) also reported significant improvement in the green and dry fodder yield at higher seed rates.

Nitrogen application@120 kg ha ${ }^{-1}$ recorded significantly superior green and dry fodder yield than control, $40 \mathrm{~kg} \mathrm{ha}^{-1}$ and $80 \mathrm{~kg} \mathrm{ha}^{-1}$ (Table 2). Higher nitrogen improved the growth parameters viz. plant height, number of leaves, dry matter and also exerted beneficial effects on cell division and elongation, and there by increased meristematic activity and photosynthetic area. Hence, more production and accumulation of photosynthates yielded higher green and dry fodder yield. These results are in conformity with the findings of Dudhat et al., (2004), Sheoran and Rana (2006) and Somashekar et al., (2015). Interaction of seed rate and nitrogen levels could not differ significantly.

\section{Economics}

The gross and net returns were markedly influenced by varied costs incurred and yield (green fodder yield) obtained under various treatments. The maximum gross and net return was recorded under application of 40 $\mathrm{kg} \mathrm{ha}^{-1}$ seed rate and $120 \mathrm{~kg} \mathrm{ha}^{-1}$ nitrogen $\left(\mathrm{S}_{2} \mathrm{~N}_{4}\right)$ and minimum with $30 \mathrm{~kg} \mathrm{ha}^{-1}$ seed rate under control treatment (Table 3). Benefit: cost ratio indicated that maximum value was recorded with use of $40 \mathrm{~kg} \mathrm{ha}^{-1}$ seed rate and $120 \mathrm{~kg} \mathrm{ha}^{-1}$ nitrogen application (2.69) under custard apple based horti-pastoral system. Similar result found by Singh et al., (2005) and Somashekar et al., (2015).

Findings indicate that under custard apple based horti-pastoral system, fodder sorghum be grown at seed rate of $40 \mathrm{~kg} \mathrm{ha}^{-1}$ with nitrogen dose of $120 \mathrm{~kg} \mathrm{ha}^{-1}$ for achieving higher net returns and benefit: cost ratio.

\section{References}

Abuswar, A.O., and Mohammed, G.G. 1997. Effect of nitrogen and phosphorus fertilization on growth and yield of some graminacea forage. Journal of Agricultural Science. 5(2): 25-33.

Ahmad, A.H., Wahid, A., Khalidg, F., Fiaz, N., and Zamir, M.S.I. 2011. Impact of organic and inorganic sources of nitrogen and phosphorus fertilizers on growth, yield and quality of forage oat (Avena sativa L.). Cercetări Agronomice in Moldova. 44(3): 39-49.

Alloway, B.J. 2004. Zinc in soils and crop nutrition. $2^{\text {nd }}$ Ed. IZA Publications, International Zinc Association, Brussels, pp. 1-116.

Anonymous. 2015a. Horticultural Statistics at a Glance. Horticulture Statistics Division, Department of Agriculture, Cooperation and Farmers Welfare, Government of India, New Delhi, pp. 372-373.

Anonymous. 2015b. Agricultural Statistics at a Glance. Directorate of Economics and Statistics, Department of Agriculture, Cooperation and Farmers welfare, Ministry of Agriculture and Farmers Welfare, Government of India, New Delhi, pp. 94-95.

Ayub, M., Mahmood, R., Tanveer, A., and Sharar, M.S. 1999. Effect of seeding density on the fodder yield and quality of two maize varieties. Pakistan Journal Biological Sciences. 2(3): 664-666. 
Ayub, M., Nadeem, M.A.T., Asif, T., Muhammed, T., and Khan, R.M.A. 2007. Interactive effect of different nitrogen levels and seeding rates on fodder yield and quality of pearl millet. Pakistan Journal of Agricultural Sciences. 44(4): 592-596.

Bargali, S.S., Singh, S.P. and Pandya, K.S. 2004. Effects of Acacia nilotica on gram crop in a traditional agroforestry system of Chhattisgarh plains. International Journal of Ecology and Environmental Sciences 30(4): 363-368.

Dudhat, M.S., Savaliy, M.G., and Ramdevputra, M.V. 2004. Response of forage maize to nitrogen and phosphorus level. Forage Research. 30(1): 34-35.

Gomez, K.A., and Gomez, A.A. 1984. Statistical procedures for Agricultural Research, $2^{\text {nd }}$ Ed: John Willey and Sons, Inc., New York, USA.

Khosla, R., Alley, M.M., and Davis, P.H. 2000. Nitrogen management in notillage grain sorghum production: I. Rate and time of application. Agronomy Journal. 92: 321-328.

Mahdi, S.S., Hasan, B., Bhat, R.A., Aziz, M.A., Singh, L., Rasool, F., Ablum, I., and Bashir, S. 2011. Effect of nitrogen, zinc and seed rate on growth dynamic and yield of fodder maize (Zea mays L.) under temperate condition. Plant Archives. 11: 165-171.

Malik, M.A., Hussain, M., and Awan, S.I. 2007. Yield response of fodder sorghum (Sorghum bicolor) to seed rate and row spacing under rain-fed conditions. Journal of Agriculture and Social Sciences. 3(3): 95-97.

Ontario Ministry of Agriculture and Food (OMAF). 2002. Agronomy guide for field crops, Publication, 610, OMAF, Queens Printer for Ontario, Toronto.

Osman, S., Abdelsalam, Y., and Abdelsalam, K. 2010. Effect of nitrogen and seed rate on growth and yield of forage sorghum [Sorghum bicolor (L.) Moench]. Sudan Journal of Science and Technology. 11: 123-135.

Patel, J.R., Singh, S.P. and Rajgopal, S. 2004. Effect of sowing date and seed rate on late sown berseem. Environment and Ecology 22 (2): 328-331.

Patil, S.T., Shirgire, S.T., Misal, N.B., and Dadhania, N.M. 2014. Effect of nitrogen and phosphorus levels on growth, yield and quality of forage maize. Ecology, Environment and Conservation. 20(2): 689-694.

Prajapati, N., Singh, G., Choudhary, P., and Jat, B.L. 2017. Effect of seed rate on yield and quality of fodder sorghum [Sorghum bicolor (L.) Monench] genotypes. International Journal of Current Microbiology and Applied Sciences. 6(2): 339-355.

Prathapar, S.A., Meyer, W.S., and Cook, F.J. 1989. Effect of cultivation on the relationship between root length density and unsaturated hydraulic conductivity in a moderately swelling clay soil. Australian Journal of Soil Research. 27: 645-650.

Reddy, T.Y., and Reddy, G.H. 2010. Principles of Agronomy, $4^{\text {th }}$ Ed. Kalyani Publishers, Ludhiana (Punjab), India.

Sheoran, R.S., and Rana, D.S. 2006. Relative efficiency of Azotobacter and nitrogen fertilizer in forage sorghum [Sorghum bicolor (L.) Moench] under semi-arid conditions. Forage Research. 32(2): 6568.

Singh, M.M., Maurya, M.L., Singh, S.P., and Mishra, C.H. 2005. Effect of nitrogen level and bio-fertilizer inoculation on productivity of forage sorghum (Sorghum bicolor). Indian Journal of Agricultural Sciences. 75(3): 167-168.

Somashekar, K.S., Shekara, B.G., Naveena, K.P., and Praveen H.G. 2015. Growth, yield and economics of multicut fodder 
sorghum (Sorghum Sudanense L.) as influenced by different seed rates and nitrogen levels. Forage Research. 40(4): 247-250.

Sweeney, D.W. 1989. Suspension N-P-K placement methods for grain sorghum in conservation tillage systems. Journal of Fertilizer. 6: 83-88.
Valadabadi, S.A., and Farhani, H.A. 2010. Effects of planting density and pattern on physiological growth indices in maize (Zea mays L.) under nitrogenous fertilizer application. Journal of Agricultural Extension and Rural Development. 2(3): 40-47.

\section{How to cite this article:}

Sanjiv Yadav, U. Sai Sravan, Tikendra Kumar Yadav and Singh, S.P. 2017. Effect of Seed Rate and Nitrogen Level on Growth and Yield of Fodder Sorghum under Custard Apple Based Horti-Pastoral System. Int.J.Curr.Microbiol.App.Sci. 6(12): 1662-1669. doi: https://doi.org/10.20546/ijcmas.2017.612.187 